\title{
Novel Methodology for the Synthesis of $p$-tert-Butylcalix[8]arene
}

\author{
BRIJ MOHAN ${ }^{1}$, LAKHBEER SINGH ARORA ${ }^{2}$, PANKAJ BHATIA ${ }^{1}$ and H. K. SHARMA ${ }^{1}$ \\ ${ }^{1}$ Department of Chemistry, Kurukshetra University, Kurukshetra-136119, India \\ ${ }^{2}$ Department of Chemistry, Indian Institute of Technology, New Delhi, India \\ brizharry17@gmail.com
}

Received 2 November 2016 / Accepted 29 November 2016

\begin{abstract}
Butylcalix[8]arene has been synthesized by condensation of $p$-tert-butylphenol and formaldehyde using $\mathrm{KOH}$ in toluene. The novel methodology produce $p$-tert-butylcalix[8]arene in high percentage purity. Compound was characterized by spectroscopic techniques such as $\mathrm{IR},{ }^{1} \mathrm{H}$ NMR, ${ }^{13} \mathrm{C}$ NMR.
\end{abstract}

Keywords: p-tert-Butylphenol, Toluene, p-tert-Butylcalix[8]arene, Synthesis

\section{Introduction}

Calix[8]arenes are the cyclic-oligomers of phenolic array possessing numerous application in recognition ${ }^{1,2}$, catalysis $^{3}$, DNA replications ${ }^{4}$ etc. Due to their potential applications in various fields $s^{1-5}$, it is a desirable to develop a simple and better approach to synthesize. Gutsche et al., reported p-tert-butylcalix[8]arene synthesized from p-tert-butylphenol and formaldehyde using sodium hydroxide as base in xylene ${ }^{6}$. Latter, different approaches have been applied for the synthesis of $p$-tert-butylcalix[8]arene ${ }^{7}$ but possesses limitations like low yield and difficult workup procedures. Recently, Falana et al., reported synthesis of $p$-tertbutylcalix[8]arene as " $7+1$ addition" of linear heptamer and diol in chloroform using TFA" Limited number of methods ${ }^{7,9}$ and their limitations prompt us to develop suitable method for the synthesis of $p$-tert-butylcalix[8]arene. Herein we reported a novel method for the synthesis of $p$-tert-butylcalix[8]arene using same approach as opted by Gutsche ${ }^{6}$. In this present work, $p$-tert-butylcalix[8]arene has been synthesized by condensation of p-tertbutylphenol and formaldehyde in presence base $\mathrm{KOH}$ using toluene as solvent in much improved yield and percentage purity.

\section{Experimental}

All chemicals and reagents were purchased from Sigma-Aldrich or Merck used without further purification. Melting points were recorded on an electric melting point apparatus (Buchi) and are uncorrected. IR spectra were recorded on a Perkin Elmer FTIR 2000 
spectrometer in $\mathrm{KBr}$ discs ${ }^{1} \mathrm{H}$ NMR and ${ }^{13} \mathrm{C}$ NMR spectra were recorded on a $300 \mathrm{MHz}$ Bruker DPX 300 instrument at room temperature using tetramethylsilane (TMS) as an internal standard.

\section{Preparation of the p-tert-butylcalix[8]arene}

p-Tert-butylphenol $25 \mathrm{~g}$ (0.166 mol), formaldehyde $15 \mathrm{~mL}(0.50 \mathrm{~mol})$ and $\mathrm{KOH} 3 \mathrm{~g}(0.011 \mathrm{~mol})$ was dissolved in toluene and stirred at room temperature for $30 \mathrm{~min}$. The contents were allowed to heat at $95-100{ }^{\circ} \mathrm{C}$ using heating mantle $2.5 \mathrm{~h}$ under gentle flow of nitrogen. If content becomes viscous by increase in temperature, then more amount of toluene were added. Then, the contents were refluxed at $110{ }^{\circ} \mathrm{C}$ for $18 \mathrm{~h}$ to observed yellow solid in the content. After $25 \mathrm{~h}$, color of solid in reaction mixture becomes off white. The reaction was further refluxed for $24 \mathrm{~h}$ and then the contents were allowed to cool at room temperature. Then solid formed was filtered and washed well with dil. $\mathrm{HCl}$, water, methanol, ethyl acetate and acetone. The solid obtained was dissolved in boiling chloroform, which were precipitated on cooling give $65 \%$ yield were collected and subjected to analysis.

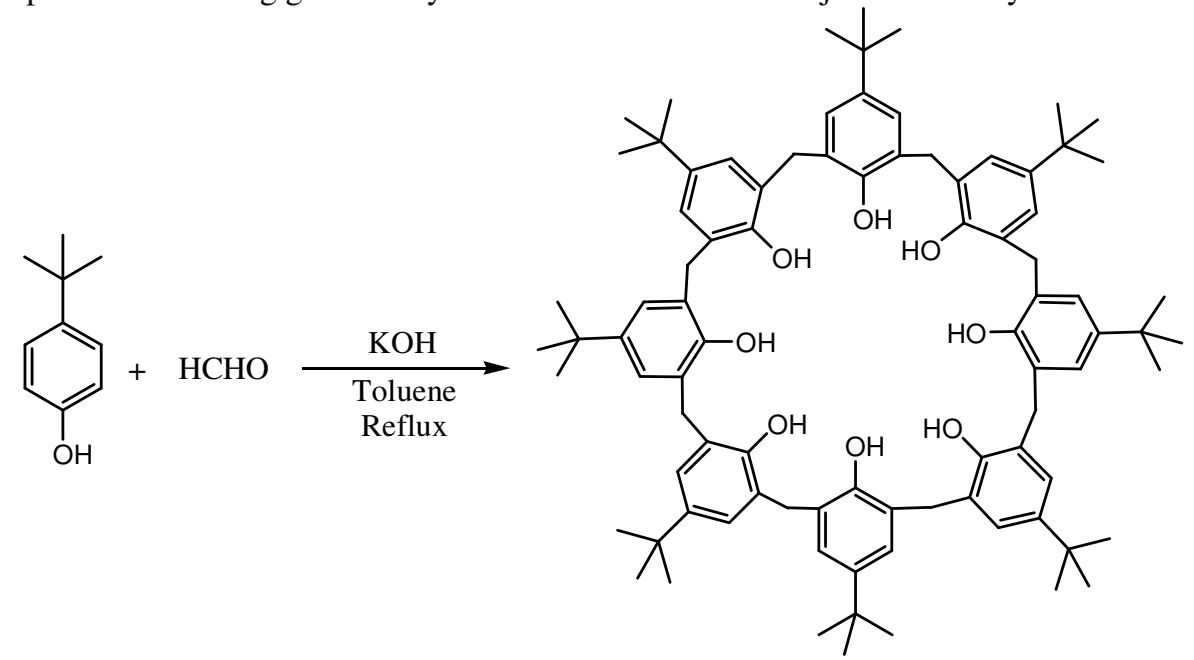

Scheme 1. Synthesis of $p$-tert-butylcalix[8]arene

\section{Results and Discussion}

p-tert-Butylcalix[8]arene was synthesized by procedure discussed in experimental section (Scheme 1) where methodology follows the condensation of p-tert-butylphenol and formaldehyde using $\mathrm{KOH}$ as base in toluene. The product obtained in cone conformation as characterized by different spectroscopic methods and physical constants like melting point, IR, ${ }^{1} \mathrm{H}$ NMR, ${ }^{13} \mathrm{C}$ NMR spectral analyses. The ${ }^{1} \mathrm{H}$ NMR spectrum ${ }^{10,11}$ of synthesized product was recorded in $\mathrm{CDCl}_{3}$ which showed characteristic peaks at $\delta 1.25 \mathrm{ppm}$ for the tert-butyl protons, pair of doublets at $\delta 3.48$ and $4.35 \mathrm{ppm}$ for bridged methylene protons (Figure 1). Singlet due to aromatic protons was observed at $\delta 7.18 \mathrm{ppm}$ along with singlet at $\delta 9.63 \mathrm{ppm}$ for hydroxyl protons (Table 1). ${ }^{13} \mathrm{C}$ NMR spectra ${ }^{11}$ was also recorded (Figure 2) in $\mathrm{CDCl}_{3}$. Data observed are shown in Table 2.

Table 1. ${ }^{1} \mathrm{H}$ NMR $\delta$ values for $p$-tert-butylcalix[8]arene

\begin{tabular}{ccccc}
\hline Protons & $-\mathrm{O} \underline{\mathbf{H}}$ & $\mathrm{Ar}-\underline{\mathbf{H}}$ & $\mathrm{Ar}-\mathrm{C} \underline{\mathbf{H}}_{2}-\mathrm{Ar}$ & $-\left(\mathrm{C}_{\mathbf{H}_{3}}\right)_{3}$ \\
\hline$\delta(\mathrm{ppm})$ & 9.63 & 7.18 & $(4.35,3.48)$ & 1.25 \\
\hline
\end{tabular}


Table 2. ${ }^{13} \mathrm{C}$-NMR $\delta$ values for $p$-tert-butylcalix[8]arene

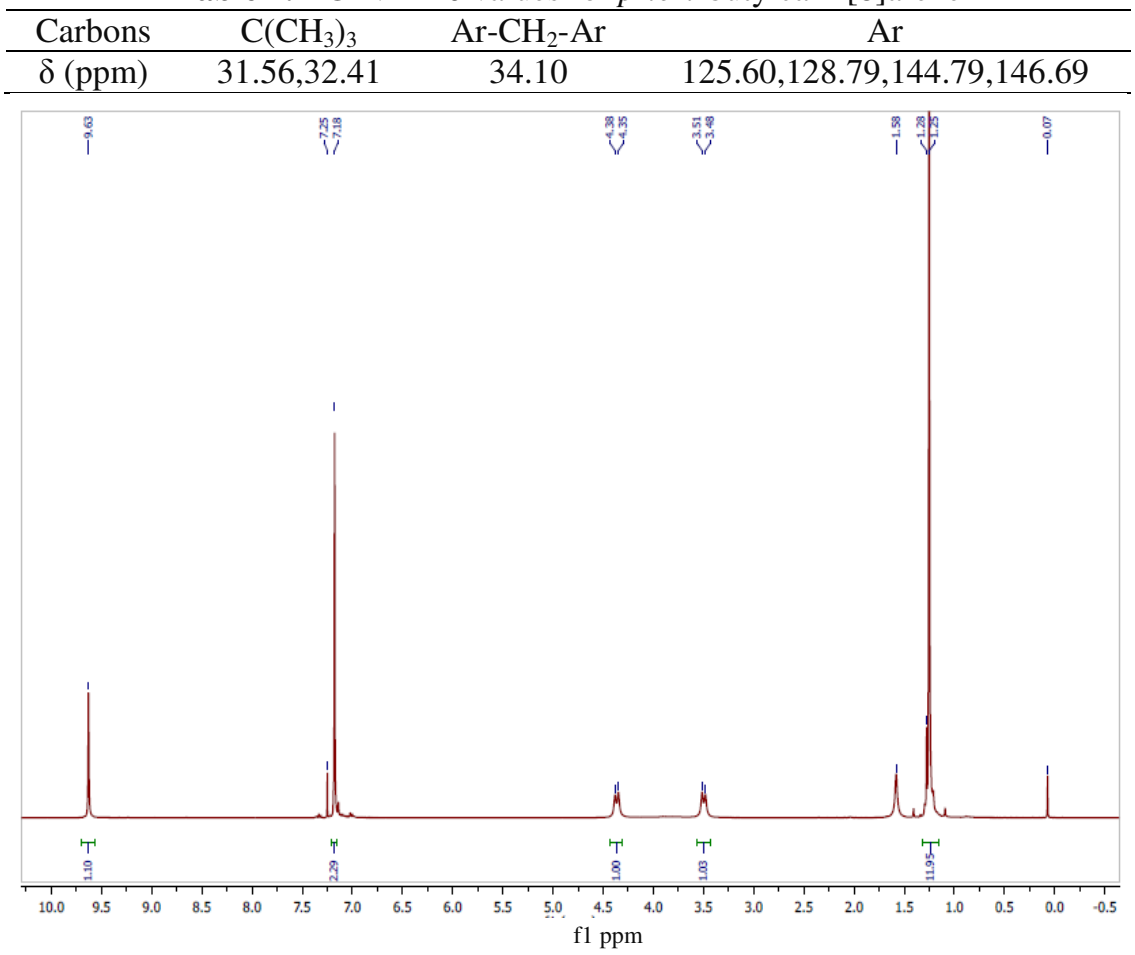

Figure 1. ${ }^{1} \mathrm{H}$ NMR spectra of cyclic-oligomer i.e. p-tert-butylcalix[8]arene from the condensation of $p$-tert-butylphenol and formaldehyde

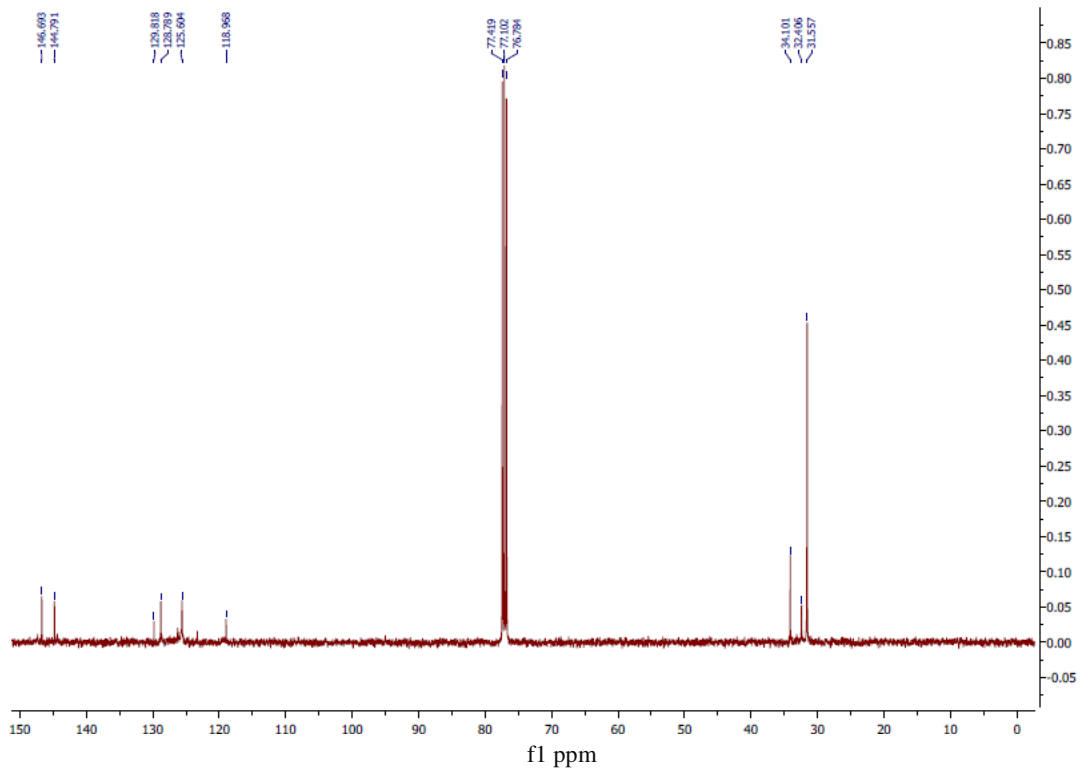

Figure 2. ${ }^{13} \mathrm{C}$-NMR spectra of cyclic-oligomer i.e. p-tert-butylcalix[8]arene from the condensation of $p$-tert-butylphenol and formaldehyde 
The intramolecular hydrogen bond character of the compound shows the low $\mathrm{OH}$ stretching frequency in the IR spectra (Figure 3). The compound shows IR (KBr): $v=3240$ $\mathrm{cm}^{-1}(-\mathrm{OH}), v=2960 \mathrm{~cm}^{-1}\left(-\mathrm{CH}_{3}\right)$.

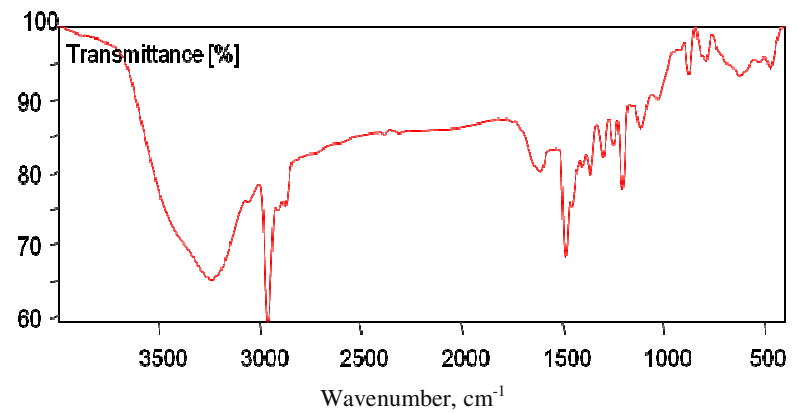

Figure 3. IR of spectra of cyclic oligomer i.e. p-tert-butylcalix[8]arene from the condensation of $p$-tert-butyl phenol and formaldehyde

\section{Physical properties}

We have also analysed the solubility of the p-tert-butylcalix[8]arene in different solvents like methanol, ethyl acetate, toluene, chloroform and acetone etc. (Table 3).

Table 3. Solubility of $p$-tert-butylcalix[8]arene in different solvents

\begin{tabular}{cccccccc}
\hline Solvents & $\mathrm{MeOH}$ & $\begin{array}{c}\text { Ethyl } \\
\text { acetate }\end{array}$ & Toluene & $\mathrm{CHCl}_{3}$ & Acetone & hexanes & $\mathrm{CH}_{2} \mathrm{Cl}_{2}$ \\
\hline Solubility & Insoluble & Insoluble & Insoluble & soluble & Insoluble & insoluble & Insoluble \\
\hline
\end{tabular}

\section{Conclusion}

In conclusion, $p$-tert-butylcalix[8]arene synthesized by condensation of $p$-tert-butylphenol and formaldehyde using $\mathrm{KOH}$ base in toluene gives better yield and purity. The methodology does not require much high temperature.

\section{Acknowledgment}

Authors like to thank University Grant Commission (UGC) and CSIR, New Delhi, India for financial assistance.

\section{Refrences}

1. Sansone F, Galletta M, Macerata E, Trivellone E, Giola M, Ungaro R, B \}ohmer V, Casnati A and Mariani M, Radiochim Acta., 2008, 96, 235-239; DOI:10.1524/ract.2008.1484

2. Meenakshi C, Sangeetha P and Ramakrishnan V, J Luminescence, 2013, 138, 129132; DOI:10.1016/j.jlumin.2012.12.055

3. Puntus L N., Chauvin A S, Varbanov S, Bünzli and J C G, Eur J Inorg Chem., 2007, 2315-2326; DOI:10.1002/ejic.200601180

4. Santa Viola, Grazia M L Consoli, Sara Merlo, Filippo Drago and Maria Angela Sortino, Pharmacology, 2010, 86, 182-188, DOI:10.1159/000317518

5. Bahram Mokhtari and Kobra Pourabdollah, Asian J Chem., 2013, 25(1), 1-12; DOI:10.14233/ajchem.2013.12058A

6. David Gutsche C, Muzaffer Iqbal and Donald Stewart, J Org Chem., 1986, 51(5), 742-745; DOI:10.1021/jo00355a033 
7. Buriks R S, Fauke A R and Munch J H, U.S. Patent 4259 464, field 1976, issued 1981.

8. Olusegun M Falana, Philip M Keehn and Robert Stevenson, Tetrahedron Letters, 2015, 56(23), 3240-3242; DOI:10.1016/j.tetlet.2011.04.053

9. Munch J H and Gutsche C D, Org. Syntheses, 1990, 68, 243; DOI:10.15227/orgsyn.068.0243

10. Zinke A. Kretz R, Leggewie E and Hossinger K, Monatsh Chem., 1952, 83(5), 12131227; DOI:10.1007/BF00899467

11. Kammerer H, Happel G and Caesar F, Makromol Chem., 1972, 162, 179. 